\title{
Reflections on recommendations for the prevention of pressure injuries during the COVID-19 pandemic
}

\section{Reflexões sobre as recomendações para prevenção de lesões por pressão durante a pandemia de COVID-19}

\section{Reflexiones sobre las recomendaciones para la prevención de lesiones por presión durante la pandemia de COVID-19}

\author{
Aline de Oliveira Ramalho, 2,*, Paula de Souza Silva Freitas ${ }^{3}$, Juliano Teixeira Moraes4, \\ Paula Cristina Nogueira ${ }^{5}$
}

ORCID IDS

Ramalho AO (D) https://orcid.org/0000-0001-6065-5488

Freitas PSS (D) https://orcid.org/0000-0001-9066-3286

Moraes JT (D) https://orcid.org/0000-0002-1109-962X

Nogueira PC (D) https://orcid.org/0000-0001-5200-1281

\section{HOW TO CITE}

Ramalho AO; Freitas PSS; Moraes JT; Nogueira PC. Reflections on recommendations for the prevention of pressure injuries during the Covid-19 pandemic. ESTIMA, Braz. J. Enterostomal Ther., 2020, 18: e2520. https://doi.org/10.30886/estima.v18.940_PT

\begin{abstract}
Objective: To reflect on specific recommendations for the prevention of pressure injuries in patients affected by the new coronavirus (COVID-19) in intensive care. Method: theoretical reflection study based on the concept of pressure injury defined by the National Pressure Injury Advisory Panel. Results: the contents were categorized into three thematic axes: specific risk factors for the development of pressure injuries for patients with COVID-19; international recommendations on pressure injuries in patients with COVID-19 and challenges for implementing recommendations for preventing pressure injuries in the face of the COVID-19 pandemic in the Brazilian scenario. Conclusion: to promote the prevention of pressure injuries in intensive care patients with COVID-19 it is essential that health professionals are able to implement advanced interventions, in order to mitigate the intrinsic and extrinsic risks specific to that patient. However, it is essential to recognize potentially preventable lesions, differentiating them from possible inevitable ones, as well as making a differential diagnosis of lesions resulting from the pathogenesis of the virus itself.
\end{abstract}

DESCRIPTORS: Pressure injury; Coronavirus infections; Critical care; Wounds and injuries; Nursing; Stomatherapy.

\footnotetext{
1. Universidade de São Paulo - Escola de Enfermagem - Programa de Pós-Graduação em Enfermagem na Saúde do Adulto São Paulo (SP), Brazil.

2. Hospital Sírio Libanês - Enfermagem Especializada - Estomaterapia - São Paulo (SP), Brazil.

3. Universidade Federal do Espírito Santo - Departamento de Enfermagem - Programa de Pós-Graduação em Enfermagem Vitória (ES), Brazil.

4. Universidade Federal de São João del-Rei - Programa de Pós-Graduação em Enfermagem - Divinópolis (MG), Brazil.

5. Universidade de São Paulo - Escola de Enfermagem - Departamento de Enfermagem Médico-Cirúrgica - São Paulo (SP), Brazil.

*Correspondence author: alineo_ramalho@hotmail.com

Received: Ago. 21, 2020 | Accepted: Out. 15, 2020
} 


\section{RESUMO}

Objetivo: refletir sobre as recomendações específicas para prevenção de lesão por pressão em pacientes acometidos pelo novo coronavírus (COVID-19) em terapia intensiva. Método: estudo do tipo reflexão teórica fundamentada no conceito de lesão por pressão definido pelo National Pressure Injury Advisory Panel. Resultados: os conteúdos foram categorizados em três eixos temáticos: fatores de risco de desenvolvimento de lesão por pressão específicos para o paciente com COVID-19; recomendações internacionais sobre lesão por pressão em pacientes com COVID-19 e desafios para implementação das recomendações de prevenção de lesão por pressão frente à pandemia de COVID-19 no cenário brasileiro. Conclusão: para promover a prevenção de lesão por pressão em pacientes de terapia intensiva com COVID-19 é fundamental que os profissionais de saúde sejam capazes de implementar intervenções avançadas, de forma a mitigar os riscos intrínsecos e extrínsecos específicos desse paciente. No entanto, é imprescindível reconhecer as lesões potencialmente evitáveis, diferenciando-as das possíveis inevitáveis, bem como a realização de diagnóstico diferencial de lesões decorrentes da própria patogenia do vírus.

DESCRITORES: Lesão por pressão; Infecções por coronavirus; Cuidados críticos; Ferimentos e lesões; Enfermagem; Estomaterapia.

\section{RESUMEN}

Objetivo: reflexionar sobre la prevención de lesiones por presión (LP) para pacientes con COVID-19 en cuidados intensivos. Método: ensayo teórico-reflexivo a la luz de las recomendaciones establecidas por el National Pressure Injury Advisory Panel. Resultados: Después de recopilar los materiales publicados, los contenidos se clasificaron en tres ejes temáticos: factores de riesgo para desarrollar LP específicos para el paciente con COVID-19; recomendaciones internacionales sobre LP en pacientes con COVID-19 y desafíos para implementar recomendaciones de prevención de LP en la pandemia de COVID-19 en el escenario brasileño. Conclusión: Para prevenir la LP en pacientes de cuidados intensivos con COVID-19, es esencial que los profesionales de la salud puedan implementar intervenciones avanzadas, para mitigar los riesgos intrínsecos y extrínsecos en este paciente. Sin embargo, es esencial reconocer las lesiones potencialmente prevenibles, diferenciando de lesiones posiblemente inevitables así como realizar un diagnóstico diferencial de las lesiones resultantes de la patogénesis del virus en sí.

DESCRIPTORES: Úlcera por Presión; COVID-19; Cuidados críticos; Heridas y Traumatismos; Enfermería.

\section{INTRODUCTION}

The disease caused by the new coronavirus, also known as COVID-19, is a disease that affects the respiratory tract, in which the virus is extremely infectious and generates varied clinical conditions, as well as different symptoms in the affected individual. It is known that most infected people will have the mildest form of the disease. However, $14 \%$ of patients may develop their critical form, requiring oxygen therapy, and at least $5 \%$ will progress to more severe pneumonia. This group needs treatment in the intensive care unit (ICU), frequently using non-invasive ventilation (NIV) and intubation with consequent support in mechanical ventilation ${ }^{1}$.

Patients admitted to the ICU, intubated under mechanical ventilation, will frequently present skin lesions, especially pressure injuries (PI), due to their compromised clinical and hemodynamic conditions, immobility in the bed, decreased sensory perception, among other intrinsic and extrinsic factors that favor the development of these injuries ${ }^{2}$.
PI is considered to be a health-related adverse event, and in most cases it is preventable ${ }^{3}$. Data from a systematic review on the prevalence and incidence of PI in the ICU showed that the cumulative prevalence of PI around the world ranged from 16.9 to $23.8 \%{ }^{2}$. In addition, there is an incidence of PI up to ten times higher in patients undergoing critical care, when compared to those hospitalized in other hospital units ${ }^{4}$. Thus, preventive interventions for PI need to be instituted since the patient's admission to the ICU, aiming to decrease incidence and prevalence rates, patient safety and quality of care.

However, the prevention of PI in the context of the coronavirus presents itself as an even more challenging situation, as the changes resulting from the infection expose the patient to greater instability, less tissue oxygenation, prolonged hospital stay in a critical unit and possible repositioning difficulty, factors that favor the development of $\mathrm{PIs}^{5}$. In addition, they are associated with aspects related to health services, such as scarcity of materials and technologies for prevention, limited human resources, among others ${ }^{5}$. 
Thus, in order to promote patient safety, since the beginning of the pandemic, international societies such as National Pressure Injury Advisory Panel (NPIAP) have been publishing general guidelines for the prevention of PI. These publications take into account specific aspects of the development of PI in patients with COVID-19. Thus, the objective of this article is to reflect on the prevention of $\mathrm{PI}$ in patients with COVID-19 in intensive care in the light of international recommendations.

\section{METHOD}

This is a theoretical reflection study based on the PI concept defined by the NPIAP 5 .

Some conceptions marked out this study, forming the frame of reference for understanding the problem. That is, these conceptions subsidized the assumptions and the delimitation for the approach of the object under study, functioning as support concepts and means for the construction of this reflection ${ }^{6}$.

Thus, the benchmark for this study was the following NPIAP recommendations for the context of COVID-197:

- Pressure injury prevention - PIP tips for prone positioning;

- Best practices for the prevention of medical devicerelated pressure injuries;

- Skin manifestations with COVID-19: the purple skin and toes that you are seeing may not be deep tissue pressure injury;

- Unavoidable pressure injury during COVID-19 pandemic: a position paper from the National Pressure Injury Advisory Panel;

\section{PRESSURE INJURY IN THE COVID-19 CONTEXT}

After reading and analyzing specific documents for patients with COVID-19 published by NPIAP $^{7}$ it was possible to categorize the content in three thematic axes:

- Specific risk factors for developing PI in the patient with COVID-19;

- International recommendations on PI in patients with COVID-19;
- Challenges for implementing the PI prevention recommendations in the COVID-19 pandemic in the Brazilian scenario.

\section{Risk factors for developing pressure injury specific to the patient with COVID-19}

There are a number of factors that increase the risk of PI in critically ill patients ${ }^{2}$. However, the infection by COVID19 is a new disease and its relationship with the development of PI still needs to be well defined. Thus, the NPIAP draws attention to the main intrinsic and extrinsic factors related to COVID-19 that can contribute to a higher risk of $\mathrm{PI}^{7}$.

\section{Intrinsic factors}

Systemic coagulopathy: the disease, a severe acute respiratory syndrome of coronavirus 2 (Sars-CoV-2), favors systemic coagulopathy with hypercoagulation and microvascular occlusion, which is associated with several clinical complications and the appearance of skin manifestations in the patient. Although cutaneous manifestations are commonly seen as purplish areas, they should not be confused with deep tissue PI, it is necessary to evaluate whether the area in question was subjected to pressure and shear ${ }^{8}$. In addition, this state of hypercoagulation may favor the development of a rapidly deteriorating PI, even when using appropriate preventive measures $^{7}$. In addition, microvascular occlusion has an impact on several organs, which favors the development of multiple organic dysfunctions, and may have a direct impact on maintaining the integrity of the skin due to the lower supply of tissue, increased interstitial fluid, with a consequent increase in skin vulnerability ${ }^{7}$.

Nutritional aspects: they are also important in this context, as the patient with COVID-19 has a hypercatabolic state with a higher risk of nutritional deficit, both due to viral infection and to interventions such as positioning in a prone, use of sedatives in high doses, among others. The development of diarrhea is common, with a consequent increase in skin moisture and dermatitis associated with incontinence ${ }^{7}$.

Gravity and hemodynamic instability: it is a very common condition in these cases, which can limit 
repositioning and promote tissue hypoxia. It should be noted that survivors of this period of instability are at high risk for PI due to the consequences of treatment, which can result in malnutrition and weakness with prolonged rehabilitation ${ }^{7}$. Considerando a gravidade da doença e independente desses fatores específicos da COVID-19, o NPIAP reforça para a manutenção das intervenções preventivas para PI em todas as fases do tratamento ${ }^{8}$. Também chama a atenção para a realização de diagnóstico diferencial entre manifestação cutânea da COVID-19 e $\mathrm{PI}^{7,8}$, assim como a análise de causa raiz do aparecimento da PI, a fim de diferenciar lesões evitáveis de inevitáveis ${ }^{7}$.

\section{Extrinsic factors}

Limited / inadequate material resources: in view of the increased demand and the severity of the patient in the pandemic context, it is possible that some health systems have difficulties in acquiring and providing adequate resources for prevention. Among them, the appropriate support surface to promote pressure redistribution ${ }^{5}$.

Limited human resources: during the pandemic period, there may be a shortage of professionals in the market, as well as the undersizing of the multidisciplinary team. It should also be considered that the reduction in the possibilities of training health professionals for best practices may compromise the implementation of preventive measures for PL.

\section{International recommendations on pressure injuries in patients with COVID-19}

\section{Recommendations for preventing pressure injuries in patients submitted to prone position}

Among the complications presented by patients affected by COVID-19, the syndrome of severe acute respiratory distress (ARDS) stands out, with a prevalence of up to $17 \%{ }^{9}$. Among the strategies for clinical management of ARDS, positioning the patient in the prone position can be used as an adjunct to improve alveolar recruitment ${ }^{10}$. Prone positioning for the treatment of severe ARDS was already adopted as a treatment strategy before the COVID-19 pandemic ${ }^{11}$, however, the practice of this positioning was more frequent in patients affected by the virus. Linked to this, the risk of developing PIs related to this positioning, which was already reported as one of the main complications, gained prominence in the world context, requiring guidelines and interventions focused on prevention. The most relevant interventions for preventing PI in the patient submitted to prone position $\operatorname{are}^{7,10}$ :

- Adequate choice of the support surface, in a way that promotes pressure redistribution, in addition to making use of auxiliary devices for positioning, such as cushions and pillows for pressure relief;

- Strict inspection of the skin before pronation is performed, with consequent protection of areas exposed to greater risk, and the use of prophylactic coverage in highrisk patients may be indicated. The main pressure points in this position are: forehead, cheek, chin, clavicle, elbow, inframammary, genitals, pelvis, knees, back and toes, as well as surrounding medical devices;

- Keeping the skin clean and dry through proper hygiene with cleansers with slightly acidic $\mathrm{pH}$. Special attention should be given to patients with urinary, faecal and mixed incontinence, as humidity is an important risk factor for the development of PI;

- Small repositioning of the patient every two or four hours. It is suggested to use the swimmer repositioning technique, in which the position of the arms and head is alternated.

\section{Recommendations for preventing Medical Device-related pressure injury}

In addition to the PIs related to the patient's positioning, special attention should be given to the prevention of Medical Device-related pressure injury (MDRPI), which can appear both during the ventral positioning and in the other positions. It is worth noting that the critical patient, in general, makes use of several invasive and non-invasive devices, many of which are essential for his survival, which exposes him to a greater risk of developing $\mathrm{MDRPI}^{7}$. Thus, it is necessary to implement specific interventions for prevention, as described below ${ }^{5,10}$ :

- Selection of the device individually, considering the appropriate size;

- Strict inspection of the skin at the insertion/placement site and around the device;

- Monitoring the tension of the fixings of the devices and promoting pressure relief, whenever possible, in addition to rotating and repositioning the device regularly, when applicable; 
- Avoid positioning the patient on the medical device, and in situations that are not possible, as in the case of prone positioning, the possibility of implementing advanced interventions, such as prophylactic coverings and/or specific positioners and pads for prevention, should be checked;

- Orientation to the patient, family and team, in order to maximize adherence to preventive measures, as well as early signaling of complaints related to the equipment in use;

- Use of thin prophylactic coverage at the device-skin interface, when applicable;

- If possible and safe, use of a Bilevel Positive Airway Pressure (BIPAP)/Contiunous Positive Airway Pressure (CPAP) facial mask, with the use of a nasal catheter, in order to alternate the pressure points and consequently reduce the risk of MDRPI, as well as reduce its severity when already installed, with special attention to the patient who presents edema in the area of application of the device;

- Establish a rotation of the oximeter placement sites and other devices, whenever possible.

\section{Recommendations on classification of unavoidable pressure injury in patients with COVID-19}

Inevitable PIs are defined as lesions developed even after proper application of all the preventive measures indicated according to the patient's risk. Or even in those cases in which the implementation of preventive interventions is not safe, as the severity and magnitude of the risk presented is excessively high. As an example, extreme severity patients are mentioned, in which the minimum repositioning can cause hemodynamic worsening ${ }^{12}$.

In the context of COVID-19, the patient's clinical and hemodynamic instability and aspects related to the pathophysiology of the virus itself, as well as the sudden change in the structures of the health services, made the NPIAP stand on how to differentiate whether PI was inevitable in complex patients affected during the pandemic ${ }^{7}$.

Thus, the NPIAP reinforces that the mere diagnosis of COVID-19 does not determine that PI is unavoidable, for that it is recommended to observe the following aspects ${ }^{7}$ :

- Conduct root cause analysis of PI, considering extrinsic and intrinsic factors to the patient and the health service;

- Perform differential diagnosis between cutaneous manifestations of COVID-19 and deep tissue PI;

- Consider that injuries in areas not subjected to pressure, shear and devices are probably not PI;
- Ensure that all preventive measures have been carried out and recorded in the patients' medical records. In this case, even if the patient develops PI, it can be considered inevitable, since all interventions were performed properly and due to the magnitude and severity the patient developed PI.

\section{Challenges for implementing pressure injury prevention recommendations in the COVID-19 pandemic in the Brazilian scenario}

In Brazil, nurses are responsible for assessing the risk of PI since the patient's admission and throughout their hospitalization, in addition to prescribing preventive and treatment care. Because they are at the forefront of coping with the pandemic, they suffer from an enormous workload, exhaustion and long-term fatigue, threat of infection, risk of developing skin lesions related to the use of personal protective equipment ${ }^{13}$, and frustration with the death of the patients they care for ${ }^{14}$. Thus, if there is no adequate dimensioning, there is a risk that care will be neglected and patient safety may be affected.

The Federal Nursing Council (Conselho Federal de Enfermagem - COFEN) established minimum parameters for nursing professionals to care for patients affected by COVID-19 and also recommended that the Technical Safety Index be $20 \%$, due to the significant increase in the number of dismissals of nursing professionals affected by COVID- $19^{15}$. However, even with COFEN's recommendation for a safe and specific dimensioning in areas of care for patients with COVID-19, what is major in the country is the dimensioning of the National Health Surveillance Agency (Agência Nacional de Vigilância Sanitária - ANVISA), according to the Resolution of the Collegiate Board (RCB) $\mathrm{n}^{\circ} 7^{16}$, which determines a smaller number of professionals when compared with the normative opinion of $\mathrm{COFEN}^{15}$.

Failure to comply with the Technical Safety Index, given the significant number of leaves of nursing professionals in the country, with 23,376 leaves by COVID-19, according to the COFEN nursing observatory, can seriously compromise both the positioning and the repositioning of the patient, systematic skin inspection, analysis of the lesion development process and other preventive measures that need to be implemented to prevent PI in the context of COVID-19. 
Undersizing and lack of training can also hamper the notification of PI in the country. According to ANVISA, PIs from stage 3 onwards are mandatory notification and it is necessary to analyze the root cause of the event. However, according to the document on incidents related to health care, with the results of the notifications made through the Health Surveillance Notification System (Notificação para a Vigilância Sanitária - NOTIVISA), in Brazil, from June 2019 to May 2020, 2,491 PIs stage 3 and 792 stage 4 were reported $^{3}$. If these figures do not reflect the reality of the incidence of PI in the country before the pandemic, it is believed that during the pandemic, for all the issues already mentioned, the underreporting and lack of analysis of the events are alarming.

In addition, in Brazil, difficulties are faced related to the availability of adequate material resources to prevent adverse events ${ }^{1}$. It is known that many institutions in the country lack basic materials to maintain the integrity of the skin even before the pandemic, however in this pandemic period this problem can be even more complex, since the expansion of the number of ICU beds, as well as the creation of field hospitals may not have been provided with adequate materials, in accordance with national and international recommendations.

\section{FINAL CONSIDERATIONS}

The COVID-19 pandemic has instituted a "new normal" in Brazil and in the world, in which everyone will have to adapt and create coping strategies. Regarding
PI prevention, it is essential that health professionals, especially the nursing team, are able to implement advanced interventions, in order to mitigate the intrinsic and extrinsic risks in this patient. However, it is essential that they are able to recognize potentially preventable injuries, as well as perform a differential diagnosis of injuries resulting from the pathogenesis of the virus itself.

Challenges with regard to undersizing, training of professionals with expertise in wound prevention and treatment, as well as training of teams were evident in the pandemic, demonstrating the need to organize health services to assist the new cases of COVID-19, as well as possible other complex situations like this.

This publication will enable greater access to updated information on NPIAP by health professionals involved in the prevention and treatment of PI, especially in the Brazilian context. In this way, the provision of clinical assistance and new research work can be guided through these reflections.

As a limitation of the study, the scarcity of specific publications on PI prevention in the pandemic context of COVID-19 stands out, as well as the daily emergence of new publications on the pathogenesis of the virus in question.

\section{AUTHORS “CONTRIBUTION}

Conceptualization: Ramalho AO; Methodology: Moraes JT; Writing - Draft: Ramalho AO e Freitas P; Writing Review \& Edition: Ramalho AO,Freitas P, Moraes JT and Nogueira PC; Supervision: Nogueira PC and Moraes JT.

\section{REFERENCES}

1. Ministério da Saúde (BR). Orientações para manejo de pacientes com COVID-19. Brasília (DF): Ministério da Saúde; 2020.

2. Chaboyer WP, Thalib L, Harbeck EL, Coyer FM, Blot S, Bull CF et al. Incidence and prevalence of pressure injuries in adult intensive care patients: a systematic review and metaanalysis. Crit Care Med 2018 Nov;46(11):e1074-81. https:// doi.org/10.1097/CCM.0000000000003366

3. Agência Nacional de Vigilância Sanitária (BR). Nota Técnica GVIMS/GGTES N03/2017. Práticas seguras para prevenção de lesão por pressão em serviços de saúde. [Internet]; 2017 [cited 21 apr 2020]. Available at: https://www20.anvisa. gov.br/segurancadopaciente/index.php/alertas/item/notatecnica-gvims-ggtes-03-2017

4. Nowicki JL, Mullany D, Spooner A, Nowicki TA, Mckay PM, Corley A et al. Are pressure injuries related to skin failure in critically ill patients? Aust Crit Care 2018 Sep;31(5):257-63. https://doi.org/10.1016/j.aucc.2017.07.004

5. European Pressure Ulcer Advisory Panel, National Pressure Injury Advisory Panel, Pan Pacific Pressure Injury Alliance. Prevention and treatment of pressure ulcers/injuries: quick reference guide. $3^{\text {a }}$ ed. EPUAP/NPIAP/PPPIA; 2019. 
6. Pessalacia JDR, Zoboli ELCP, Ribeiro IK. Equidade no acesso aos cuidados paliativos na atenção primária à saúde: uma reflexão teórica. R Enferm Cent O Min 2016 jan/abr; [cited 2020 oct 14]; 1(6):2119-39. Available at: http://www.seer. ufsj.edu.br/index.php/recom/article/view/1072

7. National Pressure Injury Advisory Panel. Unavoidable pressure injury during COVID-19 pandemic: a position paper from the National Pressure Injury Advisory Panel 2020.

8. Black JM, Berke CT. Deep tissue pressure injury: a clinical perspective regarding a condition that evolves under the skin. Innovations and Emerging Technologies in Wound Care 2020. 171-81. https://doi.org/10.1016/B978-0-12815028-3.00010-9

9. Chen N, Zhou M, Dong X, Qu J, Gong F, Han $Y$ et al. Epidemiological and clinical characteristics of 99 cases of 2019 novel coronavirus pneumonia in Wuhan, China: a descriptive study. Lancet 2020;395(10223):507-13. https:// doi.org/10.1016/S0140-6736(20)30211-7

10. Moore Z, Patton D, Avsar P, McEvoy NL, Curley G, Budri $A$ et al. Prevention of pressure ulcers among individuals cared for in the prone position: lessons for the COVID-19 emergency. J Wound Care 2020 Jun;29(6):312-20. https:// doi.org/10.12968/jowc.2020.29.6.312
11. Guérin C. Prone positioning acute respiratory distress syndrome patients. Ann Transl Med 2017 Jul;5(14):289. https://doi.org/10.21037/atm.2017.06.63

12. Edsberg LE, Langemo D, Baharestani MM, Posthauer ME, Goldberg M. Unavoidable pressure injury: state of the science and consensus outcomes. J Wound Ostomy Continence Nurs 2014 Jul/Aug;41(4):313-34. https://doi. org/10.1097/WON.0000000000000050

13. Ramalho AO, Freitas PSS, Nogueira PC. Medical devicerelated pressure injury in health care professionals in times of pandemic. ESTIMA Braz J Enterostomal Ther 2020;18:e0120. https://doi.org/10.30886/estima.v18.867_PT

14. Shen X, Zou X, Zhong X, Yan J, Li L. Psychological stress of ICU nurses in the time of COVID-19. Crit Care 2020 May;24(1):200. https://doi.org/10.1186/s13054-020-02926-2

15. Conselho Federal de Enfermagem. Parecer normativo no 002/2020 - Exclusivo para vigência da pandemia COVID-19. Brasília (DF); 2020.

16. Resolução - RDC ANVISA n. 07, de 24 de fevereiro de 2010. Dispõe sobre os requisitos mínimos para funcionamento de Unidades de Terapia Intensiva e dá outras providências. Diário Oficial da União [periódico na internet], Brasília (DF). 25 fev 2010 [cited 13 oct 2020]. Available at: https://www20. anvisa.gov.br/segurancadopaciente/index.php/legislacao/ item/rdc-07-2010 